\title{
OBITUARY
}

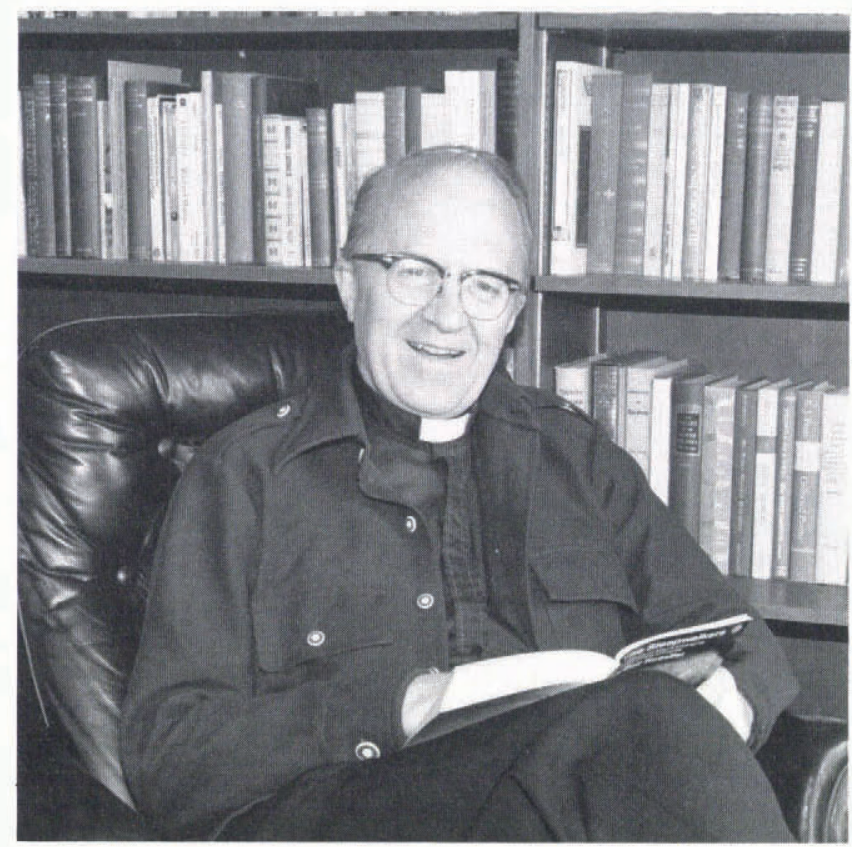

\section{FATHER THOMAS O'D. HANLEY, S.J. 1923-1987}

TOM HANLEY was born in Kenora, Ontario, Canada, the son of John Hanley and Caroline O'Donnell. Tom joined the Jesuits in 1942 and was ordained to the priesthood in 1955. His undergraduate education included a B.A. in Philosophy in 1949 and a B.S. in Physics in 1959. In 1949, he began a career as a high-school teacher of physics, chemistry, and music, which continued, except for his theological studies, until 1967. It was during his graduate studies for a doctorate in physics at Saint Louis University that Tom became interested in the physics of ice. His doctoral research was on the electrical potentials generated during the freezing of dilute aqueous solutions to ice, for which he received his Ph.D. in 1971.

Jobs for physicists were very scarce in the early 1970 s and Tom was fortunate to find a position with Professor Bernard Michel, at Laval University in Quebec, for conducting laboratory research on the formation of border ice and frazil ice. His interests in river ice expanded over the years and eventually included laboratory and theoretical research on the growth of border ice, mechanisms for the nucleation of frazil ice, acoustic emissions during the formation of frazil ice, detection of frazil ice, and the effects of salt on the formation of frazil ice. Tom spent the winter of 1974 at the Naval Arctic Research Laboratory in Barrow, Alaska, conducting research on the formation, structure, and thermal regime of fast ice in addition to helping with the sea-ice research program of the University of Alaska. He was later to describe this time as the most interesting winter of his life.

$\mathrm{He}$ returned to teaching physics, first at Wheeling College and then at Campion College at the University of Regina, where he was also dean for several years. During this time, his interests turned to defining the freezing potentials generated during soil freezing. Since the mid-1970s, Tom spent 11 summers at the U.S. Army Cold Regions Research and Engineering Laboratory working on frazil ice and freezing potentials in soils.

For those of us fortunate enough to have known him, Tom will be remembered as a gentle scholar, a humorous and happy person, and one in whom it was easy to confide. $\mathrm{He}$ was a fine and thoughtful man, willing to share his ideas, really interested in listening to others, and affected his colleagues in a way which brought out the best in them.

TOM OSTERKAMP 